\title{
Editorial
}

\section{The Ancient Pedigree of Post-Factualism}

\author{
Paul-Erik Korvela, University of Jyväskylä
}

Some recent events have sparked discussion on the role of facts in politics. There have been outcries of "post-factual democracy" and some commentators are convinced that we have entered an era of "post-truth politics". These discussions have gained impetus from the Brexit referendum, from Donald Trump's campaign, and from the success of populist politicians in power or nearly in power around Europe. Columnists and pundits one after another have been stupefied and appalled by what they see as some sort of perversion of politics: the voters have been mislead, people are making decisions based not on reason but on emotions, and facts do not seem to play a role in decision-making. These arguments seem somehow familiar, but why? Oh yes, they have been presented already in ancient Athens and ever since in Western political theory.

The people is ignorant, volatile, emotional, irrational, and ungrateful towards its leaders. The leaders are able to gain popular support for their policies with deceitful arguments. Average citizen more easily believes rumours and gossips than facts. Rhetorically skillfull agitators make use of the people's fears and promise impossible rewards. The people does not know what it is voting for and where its decision will lead. These arguments, presented in contemporary discussions on post-factual democracy, are of ancient pedigree. A quick glance to the works of Thucydides, Plato, Aristotle, Cicero, Plutarch, Livy and many others reveals the same anti-democratic stance and deep contempt towards the political ineptitude of the people. In the discussions following the Brexit referendum, similar attitudes surfaced surprisingly often, but without any historical awareness whatsoever. In stead, claims of novelty were made, as if these features of democratic politics would have appeared from outer space in 2016 to disturb the lily-pond of until then wonderfully functioning democracy.

The unwarranted claims of novelty notwithstanding, the claims of post-factualism or post-truth politics are dubious in many ways. Keeping in mind the 
developments in human sciences during the last hundred years or so, it is surprising that truth and facts are now elevated as a remedy for political demise. There have been even calls for a kind of official versions of narratives, and the dismissal of competing versions or interpretations of events. Now, we do not even need to go to the discussions of post-structuralism and post-modernism, pointing to the relativity (or at least contextuality) of all truths and hegemonic narratives. Already in antiquity it was known that facts can be described and re-described, and attached to suitable narratives serving political gains. The Latin word facta, which is plural (singular is factum), referred to things done. Ancient rhetoricians argued that things done can be presented in more than one way, and evaluative description of facts can be used to glorify one's own actions and disparage the actions of others. In rhetorics, this is known as paradiastole, or paradiastolic redescription.

The example used by Quintilian is found in the fourth book of his "Institutio Oratoria". Presume that a person is called to court to answer for his actions. Presume that the prosecutor has presented the events is such a way that the judge(s) have no doubt that the defendant is guilty as charged. Presume also that the defendant has no possibility to deny that the actions have taken place. How should one proceed from this apparent impasse? Quintilian's answer is that the defendant should re-describe the facts and present them in a different light from what the prosecutor has done. The case should be presented in the light of different motives and causes. The defendant should endeavour to describe his actions in better terms and in the light of more noble motives: "prodigality must be more leniently redescribed as liberality, avarice as carefulness, negligence as simplicity of mind". (Skinner 1999, 67-68) The ancient rhetoricians also acknowledged that vices have their neighbouring corresponding virtues, and the same actions can be described either as vicious or virtuous. In modern terms we would call this spinning of facts. The emergence of "spin doctors" as political aides is not a very recent phenomenon. It should, however, be noted that the facts themselves do not change in this act of re-description or spinning. Only the interpretation does.

Already Plato criticized the Sophists of their political rhetorics, by which untrue could be made look true and true correspondingly untrue. Thucydides argues in the "Peloponnesian War" (III.82) that as a result of party strife, "the received value of names imposed for signification of things was changed into arbitrary. For inconsiderate boldness was counted true-hearted manliness; provident deliberation, a handsome fear; modesty, the cloak of cowardice; to be wise in everything, to be lazy in everything". However, to make claims like Plato or Thucydides one has to hold a Platonic view of reality and assume that words have a "true meaning", i.e. that somewhere in the caves of the ideal world there is a set of ideas that the vocabulary of language reflects with its concepts. Modern science, of course, has abandoned these kind of claims. Lan- 
guage does not only neutrally describe reality but constructs it, and the whole reality is socially and contextually constructed. Concepts change over time and there is no grounds to claim that a concept has one and only, immutable true meaning.

Quite on the contrary, political debate is first and foremost a competition of definitions, concepts and interpretations. Facts do not speak for themselves, but they need to be attached to an interpretative framework, a narrative, a theory, or a policy. Politics is about providing a meaningful narrative of the facts and gaining support for the future-orinted policies based on that narrative. The facts can be the same, but the intreprtations are different. Many times political debate starts from limiting or expanding the set of facts that are considered relevant at certain situation and with the use of analogies and metaphors, also past events can be rehabilitated. Parliamentary democracy is largely a competion about whose facts, concepts and narratives are considered relevant. In this respect it is dubious if someone wants to provide an authoritative narrative and outlaw competing interpretations. After all, democracy is about providing different alternatives for the voters.

Also in science facts can remain the same but interpretations may still vary. The fact that an apple falls from the tree is the same in Aristotelian physics, in Newton's theory of gravity, and in Einstein's theory of relativity, but they all explain it differently. Facts do not form the results of scientific study: they must be attached to a theory that explains them in some way. Almost needless to say, different theories regarding the same facts can exist. Since Descartes at the latest, doubt has been the center of science. If we adhere to Popper's falsificationism, science does not even endeavour to attain "truth" and those arguments and claims that can not be disputed are in fact not at all scientific. In human sciences the "linguistic turn" and social constructivism have since the 1960 's relativized many truths. The "narrative turn" has pushed this approach perhaps even further, arguing that we can describe the same events and facts differently with different narratives: the choice of framework and narrative structure makes the same events look like tragedy, romance, or comedy, for instance (Frye 1957; Czarniawska 2004). The old Rankean adage of historian's task ("Wie es eigentlich gewesen ist") is replaced by the acknowledgement of historians own choices of narratives and genres (White 1973). Also in communication studies framework analysis accentuates that facts are chosen and interpreted, which creates the situation instead of merely describing some objects outside language. From a Nietzschean viewpoint, there are no facts, only perspectives (Vattimo 2011).

Given the above (and much that is not mentioned here due to lack of space), it is surprising to hear outcries demanding facts, truths and official versions of events as basis of politics. The claims that we now live in a post-factual democracy are positing a false dichotomy. For it is certainly very hard to find an era 
when truth would have been clearly appreciated in politics. Was the 1930's an era of truthful politics? Most likely not. How about early 2000's, when fabricated intel data and false claims regarding WMD's and Saddam's connections with 9/11 were used to justify invasion of Iraq? It would be quite hard to find a specific era of trutful politics, and therefore one is tempted to conlude that postfactualism has always been a feature of politics or at least democratic politics.

The analysts of post-factual democracy argue that contemporary politics draws from prejudices and fears: things do not need to be like politicians say they are, if the claim "feels true" to the audience and resonates well with their prejudices and previous ideological assumptions. One could again argue that this is not radically new in any way. It is also beside the mark to associate this with the uneducated voters. Recent studies (Achen ja Bartels 2016) have argued that even highly educated and well-informed voters make their decisions based not on political debates or campaigns, but on social identities and preexisting partisan loyalties. It is apparent that in some regions, for example, a large number of people support certain party or parties from elections to another totally regardless who the candidates are, what is the theme of the campaign etc. The arguments of post-factualism that posit some sort of ignorance on the part of the voters are reminiscent of the leftist analyses of Fascism, which posited a mass hysteria, false consciousness, primordial collective emotion and Fascist personality to explain the support of Fascism (as if the bourgeiosie or farm-owners of Italy would not have found rational reasons to support Fascism vis a vis Communism).

The argument that the demos or the voters are irrational is as old as democracy. Even though Thucydides repeatedly lambasts the people for not making wise decisions, he can offer only one instance when the ecclesia actually made a decision based on false information (Roberts 1994, 14). The problem of especially mass democracy is that the crowd can be made to support or object to almost any given subject without any rational arguments. This observation is nothing new, it can be found for instance from Robert Michels' Zur Soziologie des Parteiwesens in der modernen Demokratie (1911). Keeping in mind the history of democracy and political theory in general, the contemporary discussions of post-factual democracy offer nothing new. Pundits who lament that politics should be based on facts and rational arguments are unwittingly returning to ancient themes. The trendy argument about "different versions of truth" is simply rephrasing the obvious observation that there exists ideological differences which make people see the same things differently. 
The articles in this issue also deal with the topics discussed above. Alessandro Mulieri's article scrutinizes the ambivalence of the concept of representation. Representation, the articles argues, is elusive and includes multiple, often incompatible meanings. The problem becomes pressing when the polysemy of representation is in a kind of disconnect with the study of political representation. Mulieri's article opens new perspectives to this problem by rehabilitating a study on the conceptual history of representation by the German legal philosopher, Hasso Hoffman.

Ruben Hackler and Lucia Herrmann focus on another Germal legal philosopher, Otto Kirchheimer. The authors endeavour to re-open a debate on Kirchheimer's late work Political Justice and argue that this is a classic waiting to be read, interpreted and applied to actual cases. The book must be contextualized in order to fully grasp its ambiguities, the authors argue. They also seek to re-habilitate the concept of political justice, which has in a sense remained in the shadows. Kirchheimer's concept could be used in analysing contemporary practices and by making some clarifications the authors seek to make it more accessible for present-day scholars.

Heino Nyyssönen and Brendan Humphreys focus in their article on the often used metonym of appeasement, the Munich Agreement. They seek to contextualize Munich 1938 and scrutinize its political uses. Nyyssönen and Humphreys argue that the conjuring up of Munich in political discourse has served as a justification of use of force in international politics. This usage, the authors conlude, is to be regarded as a rather dangerous form of anti-diplomacy. The rhetorical evocations of Munich and appeasement are frequently used even in contemporary context, which highlights the significance of rhetorics in international politics. Many of the uses of Munich 1938 are in a sense misapplications, since the contexts and actors are different. It should perhaps be noted here that appeasement carries an overtone of stupidity and naivete largely because it did not work against Hitler and Stalin, but one could easily ask what kind of policy, then, would have worked against raving lunatics like Hitler and Stalin? From the fact that appeasement did not work against them, one can not infer that appeasement does not work tout court. Also in 1938 it "worked" in the sense that it bought time for Britain to prepare for war.

The fourth article, by Ari-Elmeri Hyvönen, addresses a contemprary event, the Arab Spring revolution in Egypt, from an Arendtian viewpoint. With the emergence of special kind of direct political action worldwide, associated with events and developments like the Arab Spring, Occupy Wall Street etc., we are perhaps facing redescriptions of political action and political spaces. Hyvönen focuses on the idea of resistance: the conceptual framework of dissent, contestation or protest in a way limit the possibilities of political action. Eschewing this confinement of political action, Hyvönen seeks to surpass and move beyond it by using Arendt's thought as a fulcrum. He offers a powerful and in- 
novative critique of mere "politics-as-resistance", which necessarily dims some aspects of political action. Amids the Egyptian revolution he finds an establishment of public space where freedom and happiness can be experienced.

All of the articles in this issue in their way point to the ambivalence of political language and interpretations. There are no facts that explain themselves: in stead, politics is about using events, concepts and developments in a certain interpretative framework, giving meaning to mere facts and events by attaching them to narratives. This is not necessarily "post-factualism", it is just politics.

\section{References}

ACHEN, Christopher H. ja Bartels, Larry M., 2016. Democracy for Realists. Why Elections do not Produce Responsive Government. Princeton: Princeton University Press.

CZARNIAWSKA, Barbara, 2004. Narratives in Social Science Research. London: Sage. FRYE, Northrop, 1957. Anatomy of Criticism. Princeton: Princeton University Press.

MICHELS, Robert, 1911. Zur Soziologie des Parteiwesens in der modernen Demokratie. Untersuchungen über die oligarchischen Tendenzen des Gruppenlebens. Leipzig: Werner Klinkhardt.

ROBERTS, Jennifer Tolbert, 1994. Athens on trial. The antidemocratic tradition in Western thought. Princeton: Princeton University Press.

SKINNER, Quentin, 1999. "Rhetoric and conceptual change". Finnish Yearbook of Political Thought 3, 60-73.

VATTIMO, Gianni, 2011. A Farewell to Truth. New York: Columbia University Press. WHITE, Hayden, 1973. Metahistory. The Historical Imagination in Nineteenth-Century Europe. Baltimore: The Johns Hopkins University Press. 